\title{
Optimalisasi Nilai Ekspor Ikan Tuna Hs 160414 Ke Italia Dengan Metode Mamdani
}

\author{
Luthfia Rohimah $^{1}$, Sinta Rukiastiandari ${ }^{2}$, Juarni Siregar ${ }^{3}$ \\ ${ }^{1}$ Universitas Bina Sarana Informatika \\ e-mail: luthfia.lhm@bsi.ac.id \\ ${ }^{2}$ Universitas Bina Sarana Informatika \\ e-mail: sinta.sru@bsi.ac.id \\ ${ }^{3}$ Universitas Bina Sarana Informatika \\ e-mail: Juarni.jsr@bsi.ac.id
}

\begin{abstract}
Abstract - The decline in oil and gas exports since 1990 requires the government to take policy steps to increase non-oil exports so that state revenues continue to grow. One of the non-oil and gas exports that is a mainstay of Indonesia is tunat fish which has the HS code 160414. Italy is a country where the demand for tuna is quite high. In order to maximize the value of Indonesian tuna exports to Italy, a method is needed to optimize the value of Indonesian tuna exports to Italy. The purpose of this study was to find out the best method to predict the value of tuna exports to Italy in the application of fuzzy logic in order to optimize the value of exports. The results showed that the Mamdani method was a good method. The Mamdani method has results that are close to the actual results with an error rate of $1.1 \%$, so the Mamdani method can be used as the recommended method in optimizing the optimal amount of export HS 160414 Indonesia to Italy.
\end{abstract}

Keywords: fuzzy, mamdani, optimize, export, impor.

\section{PENDAHULUAN}

Secara historis, pertumbuhan ekonomi di negara-negara maju sangat didukung oleh pertumbuhan ekspor. Ekspor merupakan penjualan produk-produk baik barang maupun jasa dari dalam ke luar negeri (Sedyaningrum, Suhadak, \& Nuzula, 2016). Sejalan dengan hal tersebut, pemerintah Indonesia juga menempatkan ekspor sebagai salah satu lokomotif pertumbuhan ekonomi Indonesia.

Setiap tahun pemerintah menetapkan target pertumbuhan ekspor dalam mendukung pertumbuhan ekonomi dan penciptaan lapangan kerja. Dalam periode 2005-2009 pemerintah dengan program "Rencana Pembangunan Jangka Menengah Nasional" menargetkan peningkatan ekspor dari 5,5 $\%$ pada tahun 2005 menjadi 8,7\% pada tahun 2009 .

Di Indonesia terdapat dua komiditi ekspor, yaitu komiditi migas dan komiditi non migas. Namun semenjak tahun 1990 ekspor migas mulai menunjukan trend yang menurun seperti yang terlihat pada tabel 1. Menurunnya ekspor migas memberi isyarat bagi pemerintah mengambil langkah kebijakan meningkatkan ekspor non migas agar pendapatan negara tetap terus bertambah.
Tabel 1. Nilai Ekspor Indonesia 2014

\begin{tabular}{|c|c|c|c|}
\hline Bulan & Total & Migas & Non Migas \\
\hline Desember & $14.621,31$ & $2.353,33$ & $12.267,97$ \\
\hline November & $13.616,20$ & $2.106,90$ & $11.509,30$ \\
\hline Oktober & $15.348,97$ & $2.469,42$ & $12.879,55$ \\
\hline September & $15.275,85$ & $2.622,61$ & $12.653,23$ \\
\hline Agustus & $14.481,66$ & $2.598,17$ & $11.883,47$ \\
\hline Juli & $14.124,13$ & $2.496,32$ & $11.627,81$ \\
\hline Juni & $15.409,45$ & $2.785,96$ & $12.623,49$ \\
\hline Mei & $14.823,60$ & $2.375,69$ & $12.447,91$ \\
\hline April & $14.292,47$ & $2.651,38$ & $11.641,10$ \\
\hline Maret & $15.192,62$ & $2.641,29$ & $12.551,33$ \\
\hline
\end{tabular}

Sumber : www.kemendag.go.id

Untuk meningkatkan nilai ekspor komoditi nonmigas, salah satu hal yang perlu diketahui adalah produk-produk unggulan serta negara-negara potensial yang akan menjadi sasaran ekspor dari produk unggulan tersebut. Selain itu, (Rachman, 2013) menambahkan bahwa untuk meningkatkan jumlah ekspor dapat dilakukan dengan mengkaji permasalahan yang muncul sehingga dapat ditindaklanjuti dengan kebijakan yang sesuai.

Arah kebijakan GBHN dalam program nasional pengembangan ekspor seperti yang dikutip 
oleh (Mastur, 2006) adalah melakukan secara proaktif negosiasi dengan kerja sama bilateral dan multilateral dalam rangka meningkatkan volume dan nilai ekspor.

Dalam kerjasama bilateral, Italia merupakan negara mitra dagang yang strategis bagi Indonesia.

Produk ekspor non-migas utama Indonesia ke Jepang meliputi: (1) copper ores and concentrates; (2) coal; briquettes, ovoids and similar solid fuels manufactured from coal; (3) nickel mattes; (4) natural rubber, balata, guttapercha; (5) refined copper and copper alloys, unwrought; (6) plywood, veneered panels and similar laminated wood; (7) paper and paperboard, uncoated, for writing; (8) insulated wire, cable and other insulated electrical conductors; (9) crustaceans, live, fresh, chilled, frozen; dan (10) unwrought aluminium. (Situs Kemendag).

Ikan tuna merupakan komoditas ikan yang paling utama didunia.produk ini menempati urutan ketiga dalam komoditas internasional. Produk utama olahan ikan tuna dalam bentuk ikan kaleh atau konsumsi langsung.

Indonesia mulai berkembang menjadi produsen ikan tuna smenjak dua puluh tahun terakhir. Negara Asia lainya yang merupakan produsen ikan tuna antara lain : Thailand, Filipina, dan Papua New Guine. Keunggulan Indonesia dibandingkan dengan negara Asia lainya adalah Indonesia mempunyai perairan yang luas dimana Indonesia tidak memerlukan impor bahan baku untuk olahan ikan tuna.

Amerika dan Eropa merupakan pengimpor ikan tuna terbesar didunia. Negara - negara Eropa itu sendiri antara lain : Inggris, Perancis, Jerman, Italia, Belanda, Spanyol, dan lainya. Dan Italia sendiri merupakan pangsa pasar utama dari produk olahan ikan tuna.

Italia merupakan negara pengimpor ikan tuna olahan karena ekspor Italia hanya $1 \%$ dari nilai impornya (ekspor US\$ 127,491 dan impor US\$ 28,878 pada bulan Juli tahun 2018). Didukung dengan trend impor Italia yang masih mengindikasikan pertumbuhan, maka dapat disimpulkan bahwa pada tahun yang akan datang permintaan (impor) akan produk ini di Italia akan semakin meningkat. Oleh karena itu, Indonesia harus mampu memaksimalkan nilai ekspor sepatu ke Jepang sebagai komoditi nonmigas untuk menutupi kekurangan dari ekspor komoditi migas yang melemah. Namun, upaya tersebut tentu memerlukan metode yang tepat.

Ada banyak metode dan teknik yang dapat dilakukan untuk menganalisis pengoptimalan ekspor, namun Indonesia harus mampu memilih dan menggunakan metode yang tepat untuk upaya pengoptimalan jumlah ekspor ini dimana permasalahan yang timbul seringkali tidak pasti. Salah satu metode yang dapat digunakan adalah metode logika fuzzy. Seperti yang dikutip dari (Komariyah, Yunus, \& Rodiyansyah, 2016), fuzzy artinya kabur atau samar, sehingga yang dimaksud dengan logika fuzzy adalah logika yang memiliki nilai kekaburan atau kesamaran antara benar atau salah.

Dipilihnya logika fuzzy dalam menganalisis pengoptimalan ekspor antara lain logika fuzzy mudah di mengerti, fleksibel, memiliki toleransi terhadap data - data yang tidak pasti, dan logika fuzzy menggunakan bahasa alami. Hal ini juga disampaikan oleh (Wibowo, 2015) bahwa logika fuzzy merupakan salah satu metode untuk melakukan analisis sitem yang mengandung ketidakpastian.

Metode yang dapat digunakan dalam pengaplikasian logika fuzzy adalah metode Mamdani, Sistem logika fuzzy metode Mamdani dikenal juga dengan nama metode Max-Min. Kusumawardani \& Purnomo menjelaskan dalam (Abrori \& Prihamayu, 2015) bahwa metode Mamdani bekerja berdasarkan aturan-aturan linguistik. Metode ini diperkenalkan oleh Ebrahim H. Mamdani pada tahun 1975. Didalam metode Mamdani untuk mendapatkan output terdapat 4 langkah, antara lain: Pembentukan himpunan fuzzy, aplikasi fungsi implikasi, Komposisi aturan, dan Penegasan.

Berdasarkan latar belakang yang telah diuraikan diatas, maka permasalahan yang dibahas dalam penelitian ini adalah mencari nilai yang paling tepat untuk digunakan dalam pengoptimalan nilai ekspor ikan tuna olahan HS 160414 ke Italia. Metode yang digunakan dalam penelitian ini adalah metode Mamdani dalam sistem logika fuzzy.

\section{Pengertian Logika Fuzzy}

Logika Fuzzy merupakan salah satu komponen pembentuk soft computing. Logika fuzzy pertama kali diperkenalkan oleh Prof. Lotfi A. Zadeh pada tahun 1965. Dasar logika fuzzy adalah teori himpunan fuzzy. Pada teori himpunan fuzzy, peranan derajat keanggotaan sebagai penentu keberadaan elemen dalam suatu himpunan sangatlah penting. Nilai keanggotaan atau derajat keanggotaan atau membership function menjadi ciri utama dari penalaran dengan logika fuzzy tersebut (Kusumadewi \& Purnomo, 2010).

$$
\text { Himpunan fuzzy merupakan suatu }
$$
pengembangan lebih lanjut tentang konsep himpunan dalam matematika. Himpunan fuzzy adalah rentang nilai-nilai, masing-masing nilai mempunyai derajat keanggotaan antara 0 sampai dengan 1. Suatu himpunan fuzzy $\tilde{A}$ dalam semesta pembicaraan $\mathrm{U}$ dinyatakan dengan fungsi keanggotaan $\mu \tilde{A}$, yang nilainya berada dalam interval $[0,1]$, dapat dinyatakan dengan:

$$
\mu \tilde{A}: \mathrm{U} \rightarrow[0,1] \text {. }
$$

Himpunan fuzzy $\tilde{A}$ dalam semesta pembicaraan U. biasa dinyatakan sebagai sekumpulan pasangan elemen $u$ ( $u$ anggota $\mathrm{U}$ ) dan derajat keanggotaannya dinyatakan sebagai berrikut: 


$$
\tilde{A}=\{(u, \mu \tilde{A}(u) \mid u \in \mathrm{U}\} .
$$

Logika fuzzy digunakan sebagai suatu cara untuk memetakan permasalahan dari input menuju ke output yang diharapkan. Logika fuzzy dapat dianggap sebagai kotak hitam yang menghubungkan antara ruang input menuju ruang output, Gelley (2000) dalam Sri Kusumadewi dan Hari Purnomo (2010,p.2).

Fungsi keanggotaan (membership function) adalah suatu kurva yang menunjukkan pemetaan titik-titik input data kedalam nilai keanggotaan yang memiliki interval antara 0 sampai 1 . Ada beberapa fungsi yang bisa digunakan iantaranya :
a.) Representasi Linear.
b.) Representasi Kurva Segitiga.
c.) Representasi Kurva Trapesium

\section{a. Representasi Linear}

Pada representasi linear, pemetaan input ke derajat keanggotaannya dapat digambarkan sebagai suatu garis lurus. Bentuk ini paling sederhana dan menjadi pilihan yang baik untuk mendekati suatu konsep yang kurang jelas. Ada 2 eadaan himpunan fuzzy yang linear

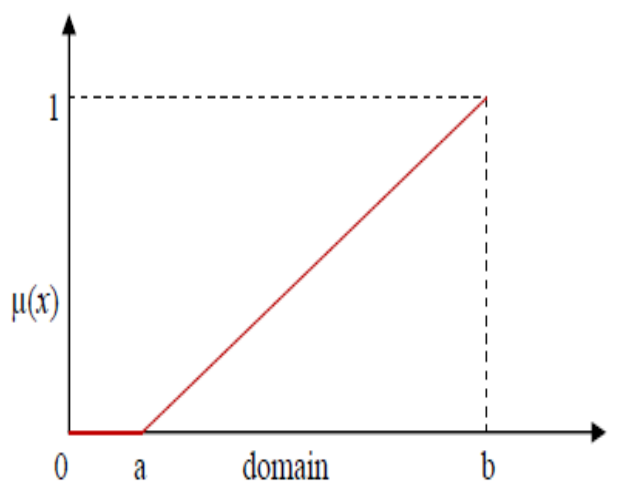

Gambar 1 Representasi linear naik

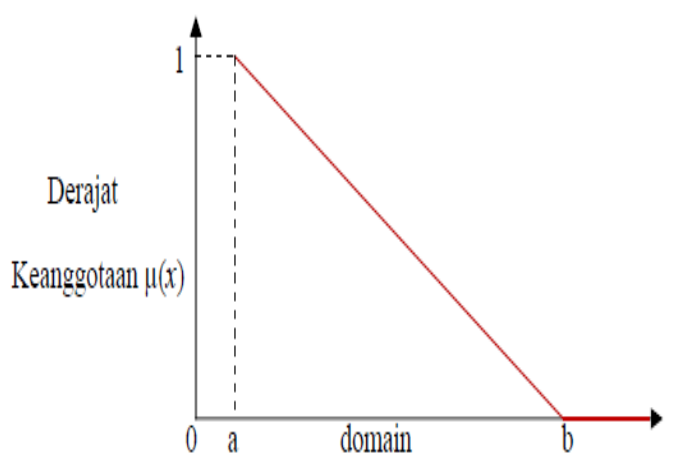

Gambar 2. Representasi linear

turun.

\section{b. Representasi Kurva Segitiga}

Representasi kurva segitiga, pada dasarnya adalah gabungan antara dua representasi linear (representasi linear naik dan representasi linear turun),

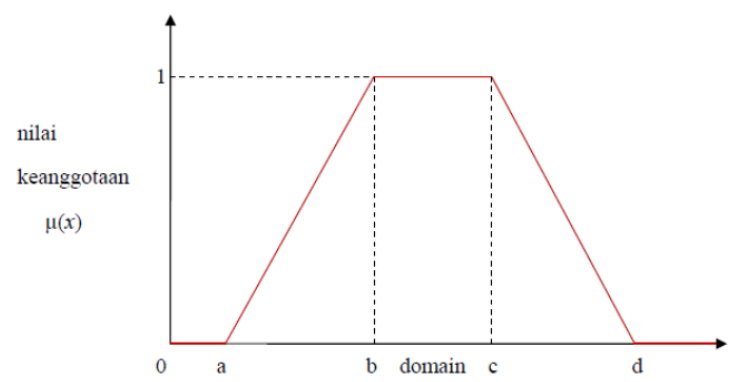

Gambar 3 Representasi Kurva Segitiga

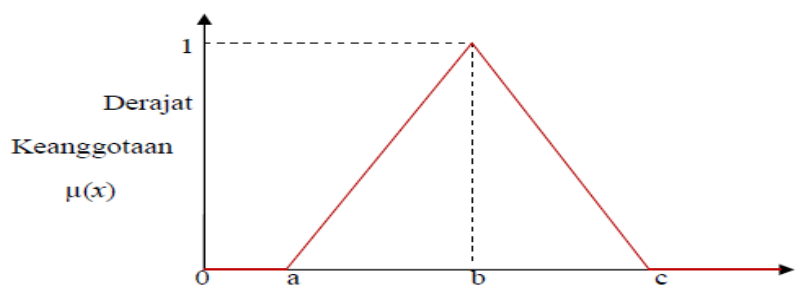

Gambar 4 Representasi Kurva Segitiga

Seperti halnya himpunan tegas (crisp set), ada beberapa operasi yang didefinisikan secara khusus untuk mengkombinasi dan memodifikasi himpunan fuzzy. Nilai keanggotaan sebagai hasil dari operasi dua himpunan sering dikenal dengan nama fire strength atau $\alpha$-cut. Ada tiga operator dasar yang diciptakan oleh Zadeh, yaitu: AND, OR, dan NOT.

Proposisi fuzzy adalah kalimat yang memuat predikat fuzzy, yaitu predikat yang dapat direpresentasikan dengan suatu himpunan fuzzy. Proposisi fuzzy yang mempunyai kebenaran tertentu disebut pernyataan fuzzy. Nilai kebenaran suatu pernyataan fuzzy dapat dinyatakan dengan suatu bilangan real dalam rentang [0,1]. Nilai kebenaran itu disebut juga derajat kebenaran pernyataan fuzzy. Bentuk umum suatu proposisi fuzzy adalah: $x$ adalah $\mathrm{A}$

Dengan $x$ adalah suatu variabel linguistik dan A adalah predikat yang Misalkan jika proposisi fuzzy " $x$ adalah $A$ "dilambangkan dengan $\mathrm{p}(x)$, pernyataan fuzzy " $x O$ adalah $A$ " dengan $\mathrm{p}(x O)$, dan derajat kebenaran $\mathrm{p}(x 0)$ dengan $\tau(\mathrm{p}(x 0))=\tilde{\mathrm{A}}(x 0)$. menggambarkan keadaan $x$. Bila $\tilde{A}$ adalah himpunan fuzzy yang dikaitkan dengan nilai linguistik A, dan $x 0$ adalah suatu elemen tertentu dalam semesta $\mathrm{X}$ dari himpunan fuzzy $\tilde{A}$, maka $x 0$ memiliki derajat keanggotaan $\mu \tilde{\mathrm{A}}(x 0)$ dalam himpunan fuzzy $\tilde{A}$. Derajat kebenaran pernyataan fuzzy " $x O$ adalah $A$ " didefinisikan sama dengan derajat keanggotaan $x 0$ dalam himpunan fuzzy $\tilde{A}$, yaitu $\mu \widetilde{\mathrm{A}}(x O)$. 
Misalkan jika proposisi fuzzy " $x$ adalah $A$ "dilambangkan dengan $\mathrm{p}(x)$, pernyataan fuzzy " $x 0$ adalah $A$ " dengan $\mathrm{p}(x 0)$, dan derajat kebenaran $\mathrm{p}(x 0)$ dengan $\tau(\mathrm{p}(x 0))=\tilde{\mathrm{A}}(x O)$.

Proposisi fuzzy yang sering digunakan dalam aplikasi teori fuzzy adalah implikasi fuzzy. Bentuk umum suatu implikasi fuzzy adalah :

Jika $x$ adalah A, maka y adalah $B$

Dengan $x$ dan $y$ adalah variabel linguistik, $A$ dan $B$ adalah predikat-predikat fuzzy yang dikaitkan dengan himpunan-himpunan fuzzy $\tilde{A}$ dan $\mathrm{B}$ dalam semesta $\mathrm{X}$ dan $\mathrm{Y}$ berturut-turut. Proposisi yang mengikuti kata "Jika" disebut sebagai anteseden, sedangkan proposisi yang mengikuti kata "maka" disebut sebagai konsekuen.

Salah satu aplikasi logika fuzzy yang telah berkembang amat luas dewasa ini adalah sistem inferensi fuzzy (Fuzzy Inference System/FIS), yaitu sistem komputasi yang bekerja atas dasar prinsip penalaran fuzzy, seperti halnya manusia melakukan penalaran dengan nalurinya. Misalnya penentuan produksi barang, sistem pendukung keputusan, sistem klasifikasi data, sistem pakar, sistem pengenalan pola, robotika, dan sebagainya.

Dalam subbab ini akan dibahas salah satu dari proses semacam itu, yaitu penentuan produksi barang. Sistem ini berfungsi untuk mengambil keputusan melalui proses tertentu dengan mempergunakan aturan inferensi berdasarkan logika fuzzy. Pada dasarnya sistem inferensi fuzzy terdiri dari empat

1. Unit fuzzifikasi (fuzzification unit)

2. Unit penalaran logika fuzzy (fuzzy logic reasoning unit)

3. Unit basis pengetahuan (knowledge base unit), yang terdiri dari dua bagian :

a. Basis data (data base), yang memuat fungsifungsi keanggotaan dari himpunanhimpunan fuzzy yang terkait dengan nilai dari variabel- variabel linguistik yang dipakai.

b. Basis aturan (rule base), yang memuat aturan-aturan berupa implikasi fuzzy.

4. Unit defuzzifikasi (defuzzification unit / unit penegasan)

Pada sistem inferensi fuzzy, nilai-nilai masukan tegas dikonversikan oleh unit fuzzifikasi ke nilai fuzzy yang sesuai. Hasil pengukuran yang telah difuzzikan itu kemudian diproses oleh unit penalaran, yang dengan menggunakan unit basis pengetahuan, menghasilkan himpunan (himpunanhimpunan) fuzzy sebagai keluarannya. Langkah terakhir dikerjakan oleh unit defuzzifikasi yaitu menerjemahkan himpunan (himpunan-himpunan) keluaran itu kedalam nilai (nilai-nilai) yang tegas. Nilai tegas inilah yang kemudian direalisasikan dalam bentuk suatu tindakan yang dilaksanakan dalam proses itu.
Sistem inferensi fuzzy Metode Mamdani dikenal juga dengan nama metode Max-Min. Metode Mamdani bekerja berdasarkan aturan-aturan linguistik. Metode ini diperkenalkan oleh Ebrahim H. Mamdani pada tahun 1975. Untuk mendapatkan output (hasil), diperlukan 4 tahapan :

1. Pembentukan himpunan fuzzy.Menentukan semua variabel yang terkait dalam proses yang akan ditentukan. Untuk masing-masing variabel input, tentukan suatu fungsi fuzzifikasi yang sesuai. Pada metode Mamdani, baik variabel input maupun variabel output dibagi menjadi satu atau lebih himpunan fuzzy.

2. Aplikasi fungsi implikasiMenyusun basis aturan, yaitu aturan-aturan berupa implikasi-implikasi fuzzy yang menyatakan relasi antara variabel input dengan variabel output. Pada Metode Mamdani, fungsi implikasi yang digunakan adalah Min.

3. Komposisi aturan Apabila sistem terdiri dari beberapa aturan, maka inferensi diperoleh dari kumpulan dan kolerasi antar aturan. Ada 3 metode yang digunakan dalam melakukan inferensi sistem fuzzy, yaitu :

Matode Max (Maximum)

Pada metode ini, solusi himpunan fuzzy diperoleh dengan cara mengambil nilai maksimum aturan, kemudian menggunakan nilai tersebut untuk memodifikasi daerah fuzzy dan mengaplikasikannya ke output dengan menggunakan operato OR (gabungan). Jika semua proporsi telah dievaluasi, maka output akan berisi suatu himpunan fuzzy yang merefleksikan kontribusi dari tiap-tiap proporsi.

Metode Additive (Sum)

Pada metode ini,solusi himpunan fuzzy diperoleh dengan cara melakukan penjumlahan terhadap semua output daerah fuzzy.

Metode Probabilistik (probor)

Pada metode ini, solusi himpunan fuzzy diperoleh dengan cara melakukan perkalian terhadap semua output daerah fuzzy.

\section{Defuzzifikasi}

Input dari proses penegasan adalah suatu himpunan fuzzy yang diperoleh dari komposisi aturan-aturan fuzzy, sedangkan output yang dihasilkan merupakan suatu bilangan real yang tegas. Sehingga jika diberikan suatu himpunan fuzzy dalam range tertentu, maka harus dapat diambil suatu nilai tegas tertentu sebagai output. Ada beberapa cara metode penegasan yang biasa dipakai pada komposisi aturan Mamdani, yaitu :

\section{Metode Centroid (Composite Moment)}


Pada metode ini, solusi tegas diperoleh dengan cara mengambil titik pusat daerah fuzzy. Secara umum dituliskan :

$$
\mathrm{Z}=\frac{\sum_{i=1}^{n} d_{i} \mu_{\tilde{A}_{i}}\left(d_{i}\right)}{\sum_{i=1}^{n} \mu_{\tilde{A}_{i}}\left(d_{i}\right)}
$$

Untuk domain diskret, dengan di adalah nilai keluaran pada aturan ke- $i$ dan $\mu \tilde{\mathrm{A}}(\mathrm{di})$ adalah derajat keanggotaan nilai keluaran pada aturan ke-isedangkan $n$ adalah banyaknya aturan yang digunakan.

$$
\mathrm{Z}_{0}=\frac{\int_{a}^{b} Z \cdot \mu_{(z)} d z}{\int_{a}^{b} \mu_{(z)} d z}
$$

Untuk domain kontinu, dengan Z0 adalah nilai hasil defuzzifikasi dan $\mu(Z)$ adalah derajat keanggotaan titik tersebut, sedangkan $Z$ adalah nilai domain ke-i.

\section{METODOLOGI PENELITIAN}

Menjelaskan kronologis penelitian, termasuk desain penelitian, prosedur penelitian (dalam bentuk algoritma, Pseudocode atau lainnya), bagaimana untuk menguji dan akuisisi data. Deskripsi dari

program penelitian harus didukung referensi, sehingga penjelasan tersebut dapat diterima secara ilmiah. Jenis penelitian yang digunakan dalam penelitian ini adalah model eksperimen.

Penelitian eksperimen ini menggunakan algoritma fuzzy dengan menggunakan metode mamdani untuk optimalisasi nilai ekspor karet remah HS 4004.

Jenis data yang digunakan dalam penelitian ini adalah data sekunder yang diperoleh penulis dari www.trademap.org dimana menyediakan data-data tentang jumlah nilai impor karet remah HS 4004 negara Amerika Serikat.

Berikut adalah kerangka pemikiran dari penilitian ini :

1. Pengumpulan Data

Data yabg digunakan dalam penelitian ini adalah data sekunder, yang di peroleh dari situs www.trademap.org, dimana data yang digunakan adalah jumlah impor sepatu kulit HS 6403 Jepang dari bulan Juli 2013 sd Maret 2014, data jumlah ekspor sepatu kulit HS 6403 Indonesia ke seluruh dunia dari bulan Juli 2013 sd Maret 2014, dan data jumomlah ekspor sepatu kulit HS 6403 Indonesia ke Jepang dari bulan Juli 2013 sd Maret 2014.

2.

entifikasi Data
Identifikasi data dilakukan untuk menentukan variabel dan semesta pembicaraan yang diperlukan dalam melakukan perhitungan dalam memprediksi jumlah ekspor sepatu kut HS 6403 ke Jepang.

3. Pengolahan Data

Berikut adalah langkah - langkah dalam pengolahan data pada penelitian ini, yaitu : Pembentukan himpunan fuzzy, Pembentukan aturan-aturan, Penentuan komposisi aturan ,Penegasan (defuzzy) Pengujian

4. . Kesimpulan

Pada tahap ini penulis mengambil kesimpulan dari hasil pengolahan data dengan metode mamdani, sugeno, dan tsukamoto.

\section{HASIL DAN PEMBAHASAN}

Untuk menghasilkan output yang di inginkan, yaitu informasi mengenai nilai ekspor maximum sepatu kulit HS 6403 ke Jepang, maka di perlukan beberapa langkah, yaitu :

1.Pembentukan himpunan fuzzy

2.Pembentukan aturan-aturan

3.Penentuan komposisi aturan

4.Penegasan (defuzzy)

Pada pembentukan himpunan fuzzy untuk kasus prediksi nilai maximum ekspor ikan tuna olahan HS 160414 ke Italia, terdapat 2 input dan output. Variabel input terdiri dari jumlah impor ikan tuna olahan HS 160414 Italia dan jumlah ekspor ikan tuna olahan HS 160414 Indonesia ke seluruh dunia, sedangkan variabel output terdiri dari jumlah ekspor ikan tuna olahan HS 160414 Indonesia ke Italia.

\begin{tabular}{|c|c|c|c|}
\hline Fungsi & Variabel & $\begin{array}{l}\text { Semesta } \\
\text { Pembicaraan }\end{array}$ & Keterangan \\
\hline Input & $\begin{array}{l}\text { Impor HS } \\
160414 \\
\text { Italia }\end{array}$ & [46 - 114] & $\begin{array}{l}\text { Jumlah } \\
\text { permintaan } \\
\text { impor sepatu } \\
\text { kulit HS } \\
160414 \\
\text { Italia dalam } \\
\text { satuan US } \\
\text { Dollar } \\
\text { thousand } \\
\end{array}$ \\
\hline
\end{tabular}

Tabel 2. Himpunan Semesta 


\begin{tabular}{|c|c|c|c|}
\hline & $\begin{array}{l}\text { Total } \\
\text { Ekspor } \\
\text { HS } \\
160414 \\
\text { Indonesia }\end{array}$ & {$[20-40]$} & $\begin{array}{l}\text { Jumlah } \\
\text { Total } \\
\text { ekspori } \\
\text { sepatu kulit } \\
\text { HS 160414 } \\
\text { Indonesia } \\
\text { yang di } \\
\text { ekspor } \\
\text { dalam } \\
\text { satuan dollar }\end{array}$ \\
\hline Output & $\begin{array}{l}\text { Ekspor } \\
\text { HS } \\
160414 \\
\text { Indonesia } \\
\text { ke Itali }\end{array}$ & {$[2,8-6]$} & $\begin{array}{l}\text { Jumlah } \\
\text { ekspor } \\
\text { sepatu kulit } \\
\text { HS 160414 } \\
\text { Indonesia ke } \\
\text { Italia dalam } \\
\text { satuan US } \\
\text { Dollar } \\
\text { thousand }\end{array}$ \\
\hline
\end{tabular}

Tabel 3. Pembentukan Aturan - Aturan

Setelah mengidentifikasi variabel - variabel yang terdapat di dalam himpunan fuzzy, langkah selanjutnya menentukan nilai linguistik pada masing - masing variabel. Untuk variabel input jumlah impor ikan tuna olahan HS 160414 Italia terdapat 2 nilai linguistik, yaitu Naik dan Turun, sedangkan untuk variabel input jumlah ekspor ikan tuna olahan HS 160414 Indonesia ke eluruh dunia terdapat 2

\begin{tabular}{|c|c|c|c|}
\hline Aturan & $\begin{array}{c}\text { Jumlah } \\
\text { impor HS } \\
6403 \\
\text { Jepang }\end{array}$ & $\begin{array}{c}\text { Jumlah } \\
\text { ekspor } \\
\text { HS } 6403\end{array}$ & $\begin{array}{c}\text { JUmlah } \\
\text { ekspor HS } \\
6403 \\
\text { Indonesia ke } \\
\text { Jepang }\end{array}$ \\
\hline R1 & Turun & Naik & Turun \\
\hline $\mathrm{R} 2$ & Turun & Naik & Naik \\
\hline R3 & Turun & Turun & Turun \\
\hline R4 & Turun & Turun & Naik \\
\hline R5 & Naik & Naik & Turun \\
\hline R6 & Naik & Naik & Naik \\
\hline R7 & Naik & Turun & Turun \\
\hline R8 & Naik & Turun & Naik \\
\hline
\end{tabular}

nilai linguistik, yaitu naik dan turun. Dan untuk variabel output jumlah ekspor ikan tuna olahan HS 160414 Indonesia ke Italia terdapat 2 nilai linguistik, yaitu Naik dan Turun.

Setelah membuat himpunan fuzzy beserta nilai linguistiknnya, langkah selanjutnya adalah membentuk aturan - aturan, dimana dalam penelitian ini atutan yang digunakan adalah aturan MIN. di penelitian ini terdapat 4 buah aturan, yaitu [R1] IF JII Turun AND JEI Naik, THEN JeII Naik [R2] IF JII Turun AND JEI Turun, THEN JeII Turun

[R3] IF JII Naik AND JEI Naik, THEN JeII Naik [R4] IF JII Naik AND JEI Turun, THEN JeII Naik.

Langkah selanjutnya setelah melakukan pembentukan aturan adalah membuat komposisi aturan. Dimana dalam penelitian ini komposisi aturan yang digunakan adalah metode MAX. Setelah melakukan komposisi aturan langkah selanjutnya adalah melakukan defuzzyfikasi, proses ini berfungsi untuk merubah nilai output yang semula bernilai linguistic menjadi nilai tegas. Untuk metode Mamdani, menggunakan pada tahap fuzzyfikasi menggunakan metode centroid dengan rumus :

$$
Z_{0}=\frac{\sum_{i=1}^{4} \alpha_{i} Z_{i}}{\sum_{i=1}^{4} \alpha_{i}}
$$

Setelah mendapatkan output berupa nilai linguistic dari proses sebelumnya, maka langkah selanjutnya adalah melakukan penegasan atau defufikasi.

Dimana di dalam proses ini yang akan dilakukan adalah merubah nilai output yang sebelumnya berupa nilai linguistic menjadi nilai tegas.

Berikut adalah cara pemecahan masalah menggunakan metode Mamdani :

1. Membuka lembar kerja Matlab

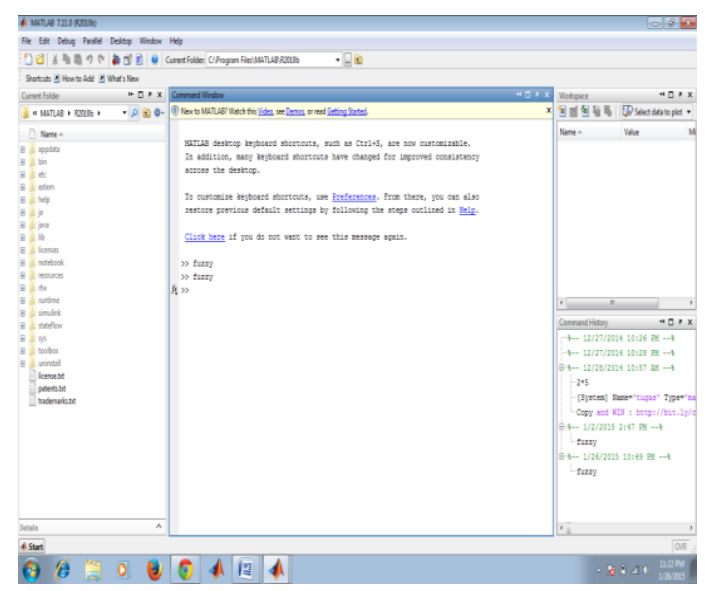

Sumber : Hasil Penelitian (2019)

Gambar 5. Tampilan awal matlab

2. Pada jendela kerja ketikan "fuzzy", maka akan muncul jendela berikut ini : 


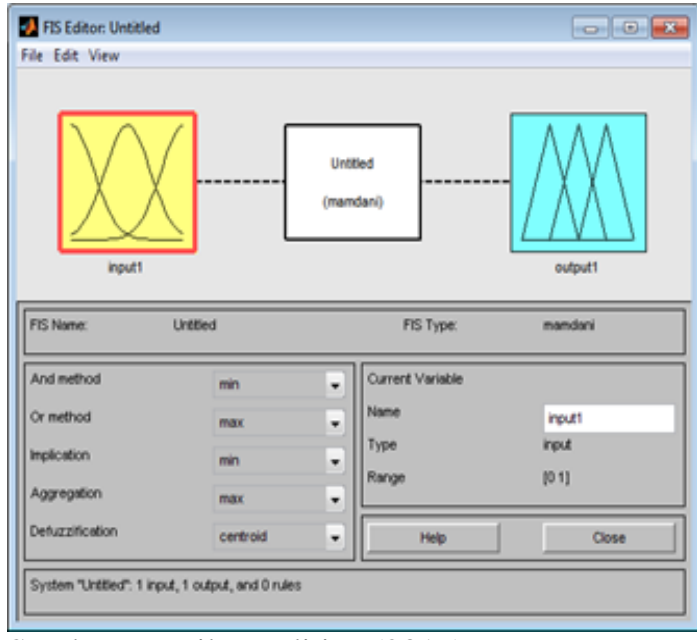

Sumber : Hasil Penelitian (2019)

Gambar 6. Tampilan pemberian input dan output

3. Langkah selanjutnya adalah mengtur fungsi dari keanggotaan input.

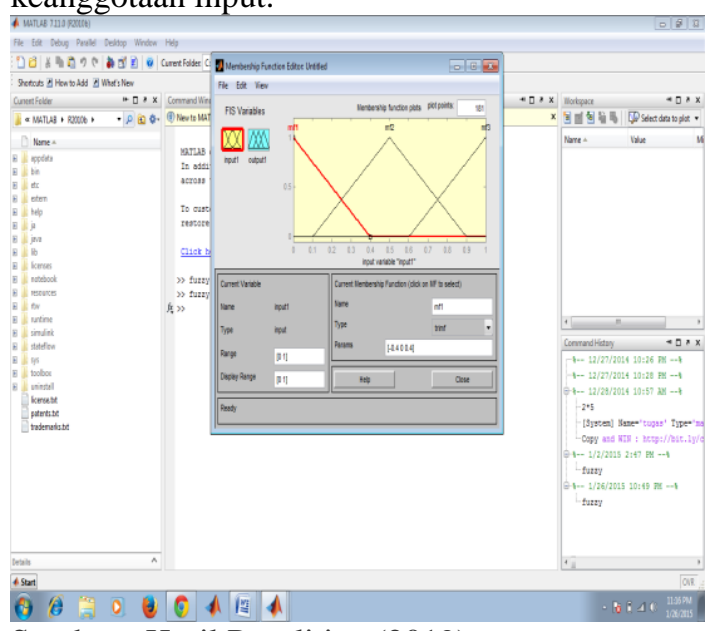

Sumber : Hasil Penelitian (2019)

Gambar 7. Tampilan pemberian fungsi keanggotaan inputan

4. Mengatur fungsi keanggotaan dari output

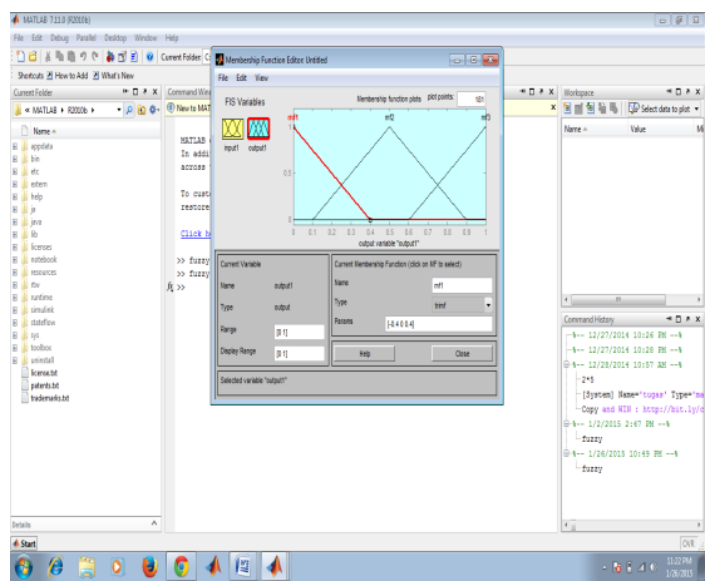

Sumber : Hasil Penelitian (2019)

Gambar 8. Tampilan fungsi keanggotaan output
5. Membentuk aturan dan logika

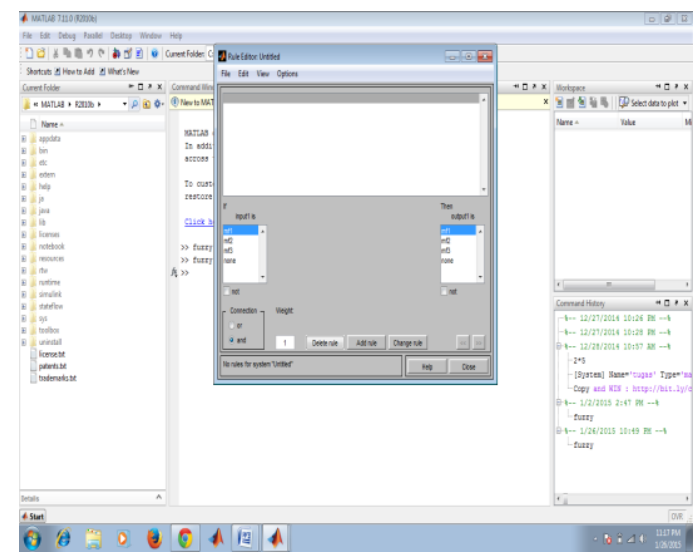

Sumber : Hasil Penelitian (2019)

Gambar 9. Tampilan membentuk aturan

6. Langkah terakhir dari proses pengujian ini adalah melihat apakah hasil sesuai dengan yang diharapkan, yaitu dengan cara memilih menu rule view pada lembar kerja.

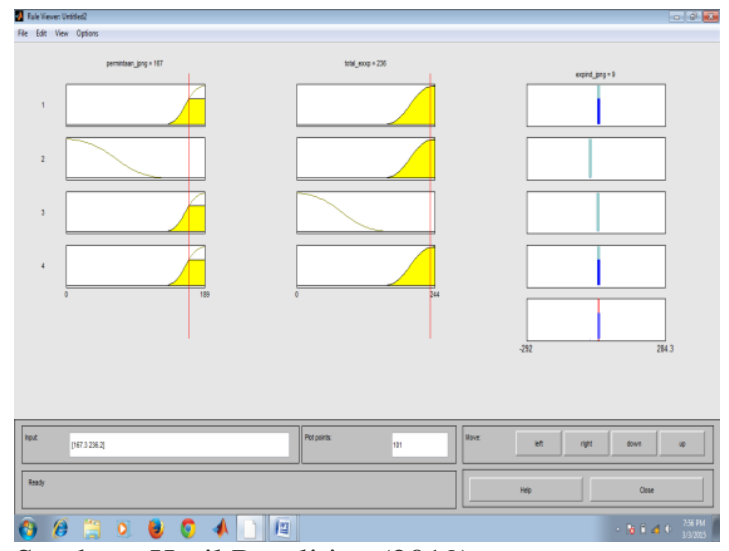

Sumber : Hasil Penelitian (2019)

Gambar 10. Tampilan Rule View

Tabel 4. Hasil Perhitungan dengan Menggunakan Mamdani,

\begin{tabular}{lllll}
\cline { 3 - 4 } & & & \multicolumn{2}{c}{ Total Ekspor Indonesia ke Italia } \\
\hline $\begin{array}{llll}\text { Bul } \\
\text { an }\end{array}$ & $\begin{array}{l}\text { Permintaa } \\
\text { n Italia }\end{array}$ & $\begin{array}{l}\text { Total } \\
\text { Ekspor } \\
\text { Indone } \\
\text { sia }\end{array}$ & Real & Mamdani \\
\hline $\begin{array}{l}\text { Juni } \\
\text { '18 }\end{array}$ & $\$ 20,5$ & $\$ 73,322$ & $\$ 3,54$ & $\$ 4,92$ \\
\hline Sumber: & Rohimah (2019) & & \\
\hline
\end{tabular}

Sumber: Rohimah (2019)

Dari data pada Tabel 3. dapat dilihat bahwa metode yang mamdani dapat digunakan karena mendapatkan hasil yang selisihnya kecil dengan data yang ada, dimana jumlah total ekspor HS 160414 Indonesia ke Italia sebenarnya adalah \$ 3.542 sedangkan hasil dari perhitungan dengan Mamdani adalah \$ 4.92, dengan nilai errornya adalah $1,4 \%$. 
Data berikut adalah data penghitungan pada Tabel 1. dengan cara yang sama, yaitu dengan metode Mamdani .

Tabel 5. Hasil Optimalisasi Ekspor HS 160414 dengan Mamdani.

\begin{tabular}{|c|c|c|c|c|}
\hline $\begin{array}{c}\text { BULA } \\
\mathbf{N}\end{array}$ & $\begin{array}{c}\text { Expor } \\
\text { HS } \\
\text { 160414 } \\
\text { Indonesi } \\
\text { a ke } \\
\text { dunia }\end{array}$ & $\begin{array}{c}\text { Impor } \\
\text { HS } \\
160414 \\
\text { Italia }\end{array}$ & $\begin{array}{c}\text { Expor } \\
\text { HS } \\
\text { 160414 } \\
\text { Indones } \\
\text { ia ke } \\
\text { Italia }\end{array}$ & $\begin{array}{c}\text { Hasil } \\
\text { Ekspor } \\
\text { HS } \\
\text { 160414 } \\
\text { Indonesi } \\
\text { a Ke } \\
\text { Italia } \\
\text { Dengan } \\
\text { Mamdai }\end{array}$ \\
\hline Okt17 & 39,080 & 46,831 & 6,022 & 4,95 \\
\hline $\begin{array}{l}\text { Nove } \\
\text { mber } \\
2017\end{array}$ & 36,834 & 61,356 & 3,486 & 4,25 \\
\hline $\begin{array}{c}\text { Desem } \\
\text { ber } \\
2017\end{array}$ & 29,405 & 49,694 & 2,805 & 4,90 \\
\hline $\begin{array}{c}\operatorname{Jan} 201 \\
8\end{array}$ & 28,818 & $\begin{array}{c}117,17 \\
4\end{array}$ & 5,309 & 4,78 \\
\hline $\begin{array}{c}\text { Feb20 } \\
18\end{array}$ & 29,530 & 53,791 & 4,636 & 4,90 \\
\hline $\begin{array}{l}\text { Mar } \\
2018\end{array}$ & 32,286 & 80,821 & 4,757 & 4,90 \\
\hline $\begin{array}{c}\text { April2 } \\
018\end{array}$ & 29,598 & 75,478 & 2,864 & 4,90 \\
\hline $\begin{array}{l}\text { Mei } \\
2018\end{array}$ & 37,098 & 81,081 & 2,876 & 4,95 \\
\hline $\begin{array}{l}\text { Juni } \\
2018\end{array}$ & 20,519 & 73,322 & 3,542 & 4,92 \\
\hline $\begin{array}{c}\text { Juli } \\
2018 \\
\end{array}$ & 37,516 & 93,105 & 5,234 & 4,95 \\
\hline $\begin{array}{c}\text { Agustu } \\
\text { s } 2018\end{array}$ & 31,671 & 71,253 & 3,043 & 4,91 \\
\hline $\begin{array}{l}\text { Septe } \\
\text { mber } \\
2018\end{array}$ & 33,728 & 54,171 & 5,575 & 4,92 \\
\hline
\end{tabular}

Sumber: Rohimah (2019)

Dalam memprediksi nilai ekspor sepatu kulit HS 6403 keJepang untuk 9 bulan kedepan terhitung dari bulan Oktober 2017 sd Juli 2018 dari ketiga metodetersebut, penulis menggunakan bantuan aplikasi Microsoft Excel dengan menggunakan bantuan fasilitas Forecasting dengan rumus=forecast(x, known_y's, known_x's)yang ada di aplikasi tersebut. Berikut langkah - langkah untuk memprediksi nilai ekspor HS 160414 ke Italiadari ketiga metode dengan bantuan Microsoft Excel :

1. Mengisikan nilai peramalan (X) dimana dengan membagi data dengan 2 (data/2) yang mana hasilnya dipakai sebagai penetapan angka pertama $\mathrm{x}$ dengan nilai $\mathrm{x}=-1$, selanjutnya untuk memberi nilai $\mathrm{x}$ arah urutan kebawah ditambah +2 dan untuk member nilai angka urutan arah keatas ditambah -2. Maka di dapat hasil sebagai berikut :

Tabel 6 Penetapan Nilai Prediksi (X)

\begin{tabular}{cc}
\hline $\begin{array}{c}\text { Y ( NilaiEkspor } \\
\text { Hs160414 } \\
\text { keIyltalia) }\end{array}$ & $\mathbf{X}$ (NilaiPrediksi) \\
\hline 6,022 & -9 \\
\hline 3,486 & -7 \\
\hline 2,805 & -5 \\
\hline 5,309 & -3 \\
\hline 4,636 & -1 \\
\hline 4,757 & 1 \\
\hline 2,864 & 3 \\
\hline 2,876 & 5 \\
\hline 3,542 & 7 \\
\hline
\end{tabular}

Sumber: Rohimah (2019)

2. Langkah selanjutnya mengisikan nilai Forecast dengan rumus =forecast(x, known_y's, known_x's), dimana jika variable Y pertama disi pada cell A2, dan variable $\mathrm{X}$ di B2 maka jika dimasukan kedalam rumus yaitu untuk baris pertama adalah= FORECAST(B2,\$A \$2:\$A10,\$B \$2:\$B \$10), maka di dapat hasil :

Tabel 7 Hasil Forecasting Nilai Ekspor t HS 160414 Ke Italia oktober 2017 sd Juli 2018

\begin{tabular}{ccc}
\hline $\begin{array}{c}\text { Y }( \\
\text { NilaiEkspor } \\
\text { Hs160414 } \\
\text { keItalia) }\end{array}$ & $\begin{array}{c}\mathbf{X} \\
\text { (NilaiPrediksi) }\end{array}$ & $\begin{array}{c}\text { Y'(Hasil } \\
\text { Forecasting) }\end{array}$ \\
\hline 6,022 & -9 & 7.2804 \\
\hline 3,486 & -7 & 7.12055 \\
\hline 2,805 & -5 & 6.9607 \\
\hline 5,309 & -3 & 6.80085 \\
\hline 4,636 & -1 & 6.641 \\
\hline 4,757 & 1 & 6.48115 \\
\hline 2,864 & 3 & 6.3213 \\
\hline 2,876 & 5 & 6.16145 \\
\hline 3,542 & 7 & 6.0016 \\
\hline
\end{tabular}

Sumber: Rohimah (2019)

Tabel 8 Hasil Perhitungan Forecasting Untuk Metode Mamdani

\begin{tabular}{ccc}
\hline $\begin{array}{c}\text { Y ( } \\
\text { NilaiEkspor } \\
\text { Hs6403 } \\
\text { Mamdani) }\end{array}$ & $\begin{array}{c}\text { X } \\
\text { (NilaiPrediksi) }\end{array}$ & $\begin{array}{c}\text { Y'(Hasil } \\
\text { Forecasting) }\end{array}$ \\
\hline 4,95 & -9 & 8.128444 \\
\hline 4,25 & -7 & 7.948278 \\
\hline 4,90 & -5 & 7.768111 \\
\hline 4,78 & -3 & 7.587944 \\
\hline 4,90 & -1 & 7.407778 \\
\hline
\end{tabular}




\begin{tabular}{lll}
\hline 4,90 & 1 & 7.227611 \\
\hline 4,90 & 3 & 7.047444 \\
\hline 4,95 & 5 & 6.867278 \\
\hline 4,92 & 7 & 6.687111 \\
\hline
\end{tabular}

Sumber: Rohimah (2019)

Setelah kita mendapatkan hasil prediksi bulan Oktober 2017 sampai dengan juni 2018 untuk metode Mamdani. Maka langkah selanjutnya adalah menghitung persentase error dari masing - masing metode yang akan dibandingkan dengan nilai prediksi nilai ekspor HS 160404 ke Italia. Metode yang memiliki nilai error yang kecil maka metode tersebut yang hasil prediksinya mendekati hasil prediksi nilai ekspor HS 160414 ke Italia.

\section{Tabel 9 Hasil Perhitungan MAPE Prediksi Oktober 2017 - Juli 2018}

\begin{tabular}{ccc}
\hline BULAN & $\begin{array}{c}\text { NIlai } \\
\text { Eskpor }\end{array}$ & Mamdani \\
\hline Okt17 & $\$ 5.841$ & $3.58 \%$ \\
\hline $\begin{array}{c}\text { November } \\
2017\end{array}$ & $\$ 5.6819$ & $11 \%$ \\
\hline $\begin{array}{c}\text { Desember } \\
2017\end{array}$ & $\$ 5.2205$ & $17 \%$ \\
\hline Jan2018 & $\$ 5.3622$ & $11 \%$ \\
\hline Mar 2018 & $\$ 5.20235$ & $11 \%$ \\
\hline Apri12018 & $\$ 5.0425$ & $11 \%$ \\
\hline Mei 2018 & $\$ 4.88265$ & $11 \%$ \\
\hline Juni 2018 & $\$ 4.7228$ & $11 \%$ \\
\hline Juli 2018 & $\$ 4.56295$ & $11 \%$ \\
\hline
\end{tabular}

Sumber: Rohimah (2019)

\section{KESIMPULAN}

Salah satu komiditi yang mempunyai nilai yang cukup tinggi dari sektor non migas salah satunya adalah ikan tuna olahan HS 160414. Dan salah satu negara tujuan utama ekspor ikan tuna olahan HS 160414 ada negara Italia. Untuk itu di perlukan suatu metode yang dapat digunakan dalam memprediksi jumlah optimal ekspor ikan tuna olahan HS 160414 ke Italia.

Metode yang dapat digunakan dalam optimalisasi jumlah ekspor ikan tuna olahan HS160414 ke Italia adalah dengan menggunakan metode Mamdani. Berdasarkan perhitungan diatas dari permintaan Italia pada bulan Juni 2018 sebesar \$20.519 dan total ekspor Indonesia untuk HS160414 sebesar \$ 73.332 didapat hasil Mamdani sebesar $\$ 4.920$.
Dari metode yang digunakan maka metode Mamdani yang mendapatkan hasil yang dekat dengan hasil sebenarnya dengan tingkat error $1,1 \%$, sehingga metode Mamdani bisa dijadikan metode yang direkomendasikan dalam optimalisasi jumlah optimal ekspor HS 160414 Indonesia ke Italia.

\section{REFERENSI}

Abrori, M., \& Prihamayu, A. H. (2015). Aplikasi Logika Fuzzy Mamdani dalam Pengambilan Keputusan Penentun Jumlah Produksi. Kaunia, XI(2), 91-99.

Iswari, L., \& Wahid, F. (2005). Alat Bantu Sistem Inferensi Fuzzy Metode Sugeno Orde Satu. In Seminar Nasional Aplikasi Teknologi Informasi 2005 (Vol. 2005, pp. 59-64).

Komariyah, S., Yunus, R. M., \& Rodiyansyah, S. F. (2016). Logika Fuzzy dalam Sistem Pengambilan Keputusan Penerimaan Beasiswa. Jurusan Teknik Informatika Fakultas Teknik Universitas Majalengka, 6169.

Kusumadewi, Sri dan Purnomo, Hari (2010). Aplikasi Logika Fuzzy Untuk Pendukung Keputusan. Yogyakarta: Graha Ilmu.

Mastur. (2006). Strategi Peningkatan Ekspor Indonesia dalam Perdagangan Bebas. AKSES: Jurnal Ekonomi Dan Bisnis, 1(1), 3145.

Rachman, I. (2013). Analisis Kinerja Ekspor Komoditi Perkebunan terhadap Pertumbuhan Ekonomi di Sulawesi Utara. EMBA, 1(3), 401-410.

Sedyaningrum, M., Suhadak, \& Nuzula, N. F. (2016). Pengaruh Jumlah Nilai Ekspor, Impor, dan Pertumbuhan Ekonomi terhadap Nilai Tukar dan Daya Beli Masyarakat di Indonesia. Jurnal Administrasi Bisnis (JAB), 34(1), 114-121.

Sulistiani, E., \& Noris, S. (2016). Penerapan FIS Metode Tsukamoto untuk Menentukan Kelayakan Pemberian Kredit. Jurnal Informatika Universitas Pamulang, 1(1), 2227.

Wachdani, R., Abidin, Z., \& Yaqin, M. A. (2012). Pengatur Pola Menu Makanan Balita untuk Mencapai Status Gizi Seimbang Menggunakan Sistem Inferensi Fuzzy Metode Sugeno. MATICS, 4(5).

Wardani, A. R., Nasution, Y. N., \& Amijaya, F. D. T. (2017). Aplikasi Logika Fuzzy dalam Mengoptimalkan Produksi Minyak Kelapa Sawit di PT. Waru Kaltim Plantation Menggunakan Metode Mamdani. Jurnal Informatika Mulawarman, 12(2), 94-103.

Wibowo, S. (2015). Penerapan Logika Fuzzy 
Dalam Penjadwalan Waktu Kuliah. Jurnal Informatika UPGRIS, 1(Juni), 59-77.

www.kemendag.go.id

www.trademap.org

\section{PROFIL PENULIS}

Luthfia Rohimaj, Tahun 2007 Lulus S1 Falkultas Teknologi industri, Jurusan Teknik Informatika. Tahun 2015 Lulus S2 Magister Ilmu Komputer STMIK Nusamandiri.
Sinta Rukiastiandari. Tahun 2008 Lulus S1 Fakultas Teknologi Industri, Jurusan Teknik Informatika Universitas Gunadarma. Tahun 2011 Lulus S2 Magister Manajemen Sistem Informasi, Universitas Gunadarma.

Juarni Siregar. Tahun 2010 lulus S1 Pendidikan Matematika STKIP Pelita Bangsa. Tahun 2015 Lulus S2 Magister Komputer STMIK Nusamandiri 